TEME, г. XLIV, бр. 4, октобар - децембар 2020, стр. 1481-1498

\begin{tabular}{lr}
\hline \hline Оригинални научни рад & https://doi.org/10.22190/TEME200922087K \\
Примљено: 22.9 .2020$. & UDK 336.143:347.764
\end{tabular}

Одобрено за штампу: 1. 12. 2020.

\title{
FINANCIAL REPORTING ON COMPREHENSIVE INCOME - THE CASE OF INSURANCE COMPANIES FROM THE REPUBLIC OF SERBIA
}

\author{
Nemanja Karapavlović1, Vladimir Stančić ${ }^{*}$, Evica Petrović \\ ${ }^{1}$ University of Kragujevac, Faculty of Economics, Kragujevac, Serbia \\ ${ }^{2}$ University of Niš, Faculty of Economics, Niš, Serbia \\ *vstancic@kg.ac.rs
}

\begin{abstract}
The objective of the paper is to research if the specificities of insurance business influence the fact that in insurance companies more components of other comprehensive income occur, as well as if in insurance companies different components of other comprehensive income are represented compared to the companies from the real sector. Furthermore, the paper should show if net income and net comprehensive income of insurance companies are significantly different, and which one of them is more volatile over time. The results of the research suggest that in the insurance companies more components of other comprehensive income are represented than in the companies from the real sector, as well as that that the most represented components of other comprehensive income in insurance companies are not different from the real sector companies, but that their frequency of appearance is higher. Statistical analysis conducted at the level of population has shown that net income and net comprehensive income are not significantly different. Also, it was established that net comprehensive income of insurance companies was more volatile over time than net income. However, by segmentation of total population according to types of insurance dealt with by insurance companies to life insurance companies, non-life insurance companies and those doing activities of both life and non-life insurance, it was established that in certain cases net income and net comprehensive income are statistically significantly different, as well as that net income was more volatile than net comprehensive income.
\end{abstract}

Key words: net comprehensive income, net income, net other comprehensive income, insurance companies.

\section{ФИНАНСИЈСКО ИЗВЕШТАВАЊЕ О УКУПНОМ РЕЗУЛТАТУ - СЛУЧАЈ ОСИГУРАВАЈУЋИХ ДРУШТАВА ИЗ РЕПУБЛИКЕ СРБИЈЕ}

\section{Апстракт}

Циљ рада је да се истражи да ли специфичности делатности осигурања утичу на то да се у осигуравајућим друштвима појављује више компоненти осталог укупног 
резултата, као и то да ли су у осигуравајућим друштвима заступљене другачије компоненте осталог укупног резултата у поређењу са предузећима из реалног сектора. Осим тога, рад треба да покаже да ли се нето резултат и нето укупан резултат осигуравајућих друштава значајно разликују и који од њих је променљивији у времену. Резултати истраживања сугеришу то да је у осигуравајућим друштвима заступљено више компоненти осталог укупног резултата него у предузећима из реалног сектора, као и то да се најзаступљеније компоненте осталог укупног резултата код осигуравајућих друштава не разликују од предузећа из реалног сектора, али да је њихова учесталост појављивања већа. Статистичка анализа спроведена на нивоу популације показала је да се нето резултат и нето укупан резултат не разликују значајно. Такође, утврђено је да је нето укупан резултат осигуравајућих друштава променљивији у времену у односу на нето резултат. Међутим, сегментацијом укупне популације према врстама осигурања којима се баве осигуравајућа друштва на она која обављају искључиво делатност неживотног осигурања, она која обављају искључиво делатност животног осигурања и она која обављају делатности и неживотног и животног осигурања, утврђено је да се у извесним случајевима нето резултат и нето укупан резултат статистички значајно разликују, као и да је нето резултат променљивији од нето укупног резултата.

Кључне речи: нето укупан резултат, нето резултат, нето остали укупан резултат, осигуравајућа друштва.

\section{INTRODUCTION}

International Accounting Standard (IAS) 1 allows that comprehensive income $(\mathrm{CI})$ is alternatively presented in one of the two following ways (International Accounting Standards Board (IASB), 2018, paragraph 81): (1) in a single statement of profit or loss and other comprehensive income, i.e. the statement of comprehensive income or (2) in two statements - a statement of profit or loss, displaying net income (NI) (profit or loss) components and statement of comprehensive income, beginning with NI from statement of profit or loss. and then displaying components of other comprehensive income (OCI). Reporting entities in the Republic of Serbia (RS), which prepare their financial statements based on IFRS, display the income in two financial statements - Income statement and Statement of other comprehensive income. Thus, the open option present in IAS 1, i.e. two (or more) possibilities for the accounting treatment of the same accounting problem (Obradović, 2014, p. 233), was eliminated by prescribing a unique solution.

Annual set of financial statements by insurance companies (IC) in RS consists of the same financial statements as the annual set of financial statements of the companies from the real sector, which prepare financial statements according to the IFRS. Regardless of this, due to the specificities of the insurance business, there are differences between forms and contents of the financial statements for IC and the real sector (Stančić, 2016, p. 35). These differences are reflected in the fact that, apart from the positions usual for all business entities, financial statements of IC also 
contain numerous specific positions characteristic only for the insurance business (Jovković, 2018, p. 112). In this respect, the income statement of IC contains certain categories of incomes and expenses, the character of which is determined by the specificities of the insurance business (Jovković, 2018, pp. 116-117), and these are not shown in the income statement of a company from the real sector (for example, incomes from insurance premiums and expenses for benefits and claims paid). The Form of the Statement of other comprehensive income of IC is partially different from the form of the same statement prescribed for companies, cooperatives, and entrepreneurs (hereinafter the companies from the real sector).

The research subject in this paper is the practices of financial reporting on CI of insurance companies from RS in the period from 2014 to 2018. The objective of the paper is to research if the insurance business influences the fact that more components of OCI are represented in IC, as well as if different components of OCI are represented in IC compared to the companies from the real sector. Moreover, the paper should show if NI (profit or loss) and net comprehensive income (NCI) of IC are significantly different and which one of them is more variable over time. Finally, the paper should provide insight into the representation and variability of the mentioned categories in certain segments of the insurance market - the sector of life insurance, the sector of non-life insurance and the mixed sector (life and non-life insurance). According to the subject and objectives of the research, the following research hypotheses have been tested in the paper:

$\mathrm{H}_{1}$ : The number and representation of OCI components in IC is different from the number and representation of OCI components in the companies from the real sector.

$\mathrm{H}_{2}$ : Components of OCI in IC make NCI significantly different from NI. $\mathrm{H}_{3}$ : NCI of IC is more volatile in time than NI.

Apart from the introduction, conclusion and the list of used references, the paper consists of three parts. In the first part theoretical and empirical considerations of $\mathrm{CI}$ are presented. The second part of the paper is related to presenting information basics and defining the methodology of research. In the third part, the results of the conducted empirical research are shown, followed by a discussion and general conclusions. Starting from the set hypotheses, the basics for their acceptance or non-acceptance were especially indicated in the conclusion.

\section{LITERATURE REVIEW}

\section{Theoretical Background on Comprehensive Income}

Under the influence of the expansion of the number of users of financial statements and the growth of their information demands, financial statements are being permanently adjusted and it improves the procedures and tools for generating and displaying information (Stančić, Dimitrijević, \& 
Stančić, 2013, p. 1881). In this respect, the demand for calculation and presentation, CI, is only one of the representative examples. CI was introduced in the accounting literature in 1980 in the Statement of Financial Accounting Standards (SFAS) 3 -Elements of Financial Statements of Business Enterprises, developed by Financial Accounting Standards Board (FASB) in USA. In this document, $\mathrm{CI}$ is defined as:

"the change in equity (net assets) of a business enterprise during a period resulting from transactions and other events and circumstances from non-owner sources."

In June 1997 FASB published SFAS 130 - Reporting Comprehensive Income (now: ASC - Topic 220: Comprehensive Income). This document demanded the financial reporting on $\mathrm{CI}$ and its components to be an integral part of general purpose external financial reporting (Brauchle \& Reither, 1997). However, as Khan, Bradbury, \& Courtenay (2018, p. 280) noticed, the USA is not the first state in which the obligation of reporting on CI was prescribed. Namely, in the United Kingdom in 1992, according to regulations on financial reporting of that time, it was demanded that "a statement of total recognized revenues and expenses" is shown and that represented an addition to the profit and loss account. The last item of the mentioned statement was similar to CI defined by FASB. In the context of IFRS, financial reporting on CI, in its present form, was introduced in September 2007, when IAS 1 was modified (Rees \& Shane, 2012, p. 791) by which CI was defined in an almost identical way as according to SFAS 6, i.e. as:

"the change in equity during a period resulting from transactions and other events, other than those changes resulting from transactions with owners in their capacity as owners." (IASB, 2018, paragraph 7)

CI of a period is the sum of NI and OCI of a period. In other words, CI in net amount (after tax deduction) represents the sum of NI established after the exemption of income tax and net OCI, i.e. OCI after the deduction of tax on OCI. NCI of a period is equal to NI of a period if a reporting entity has no component of OCI over that period. CI is different from NI by amounts of some items that were included in it, and which were not encompassed by the process of determination of NI. These items, essentially, represent the components of OCI. They include non-realized, i.e. through transactions with third parties still nonconfirmed value changes of assets and liabilities (Stojilković \& Spasić, 2002, p. 15). The most significant components of OCI according to IAS 1 (IASB, 2018, paragraph 7) are: changes in revaluation surplus of property, plant, equipment and intangible assets, re-measurements of defined benefit plans, gains and losses arising from translating the financial statements of a foreign operations, gains and losses on financial assets measured at fair value through OCI, the effective portion of gains and losses on hedging instruments in a cash flow hedge and the gains and losses on hedging 
instruments that hedge investments in equity instruments measured at fair value through OCI. The components of OCI companies from the real sector are mainly related to secondary, i.e. non-business activities of the company. However, it does not have to be the case with IC, because some of the previously stated components of OCI, such as, for example, gains and losses on financial assets measured at fair value through OCI, can be relevant for the assessment of performances of an IC (Maines \& McDaniel, 2000, p. 180). This is because IC (1) perform multiple functions, in addition to its basic protection function (the function of mobilization and allocation of resources, the function of saving and the function of managing various forms of financial risk) and (2) represent significant investors on world financial market (Popović, Stanković, \& Marjanović, 2020, p. 10). The components of OCI can be divided to (a) the components that can be subsequently, i.e. in future periods reclassified into the profit and loss statement, i.e. included in $\mathrm{NI}$ and (b) the components that subsequently, i.e. in future periods cannot be included in NI (Obradović \& Karapavlović, 2017, p. 117).

\section{Empirical Background on Comprehensive Income}

Although the primary objective of certain research (De Cristofaro \& Falzago, 2014, pp. 26-27; Dhaliwal, Subramanyam, \& Trezevant, 1999, p. 51; Goncharov \& Hodgson, 2011, p. 34; Kabir \& Laswad, 2011, pp. 278279; Kubota, Suda, \& Takehara, 2011, pp. 152-153) was not to determine the correlation between NI and CI, in their results it can be observed that there is a high correlation between these two forms of income. Based on the research conducted at the sample of 90 companies from the USA, Ketz (1999, pp. 79-96) has found that average values of NI and NCI at the sample level are not significantly different. The segmentation of the sample according to the business activity discovered that average value participation of non-realized components of the results related to securities available for sale is bigger in the banks and IC than in the companies from the non-financial sector. Kreuze \& Newell (1999, p. 53) established that, in the majority of 100 randomly selected companies from the Fortune 500 list, CI and NI are not statistically significantly different. Ngmenipuo (2015) and Păşcan (2014) established that earnings per share, if NI, that is $\mathrm{CI}$ is used for its calculation, are not statistically significantly different. Mahmood \& Mahmood (2019), by analyzing 100 companies of different business activities from the USA, determined that, on average, NI and $\mathrm{NCI}$ are significantly different in most companies, as well as that most companies had negative OCI, which was, according to their opinion, significant for the interpretation of earnings per share. Namely, they consider that taking into account $\mathrm{OCI}$ when assessing company performances resulted in different conclusions then if the conclusions were made only based on NI. Lapková \& Stašová (2014) examined, among other things, whether return on assets calculated by usage of NI as numerator is different in relation to 
return on assets calculated by adding the items of OCI that can be reclassified into profit or loss to NI as numerator. According to the same principle, the influence on return on equity was examined. The items of OCI that can be reclassified into profit or loss had the influence on these two indicators of profitability only in the case of financial institutions, but not in case of non-financial companies.

Given that today's model of financial reporting is characterized by the simultaneous use of several measurement attributes, the current model of calculating income of the period is characterized by moving away from the traditional approach that was valid in time of the domination of historical cost and moving closer to the approach based on fair value. Namely, when calculating income of the period, in addition to recognizing realized gains, realized and non-realized losses, some, but not all, non-realized gains are recognized. Since non-realized gains, but also non-realized losses, are under the influence of price changes on the market which are the basis for subsequent measurement of some assets and liabilities, it is reasonable to expect that these non-realized gains and/or losses will be variable, which will influence the variability of CI from period to period under the influence of OCI to be higher than variability of NI. On the basis of the examination of financial statements preparers, Smith \& Tse (1998, pp. 75-86) emphasize that the components of OCI increase the volatility of CI, although the risk of company is unchanged. Khan \& Bradbury (2014, pp. 80-81; 2016, pp. 736738 ) found by empirical analysis of 2.500 American non-financial companies, respectively 92 non-financial companies from New Zealand, that CI is more volatile than NI. Henry (2011, p. 88) analyzed the companies included in the index basket S\&P 500 and found that the half of the companies' standard deviation of $\mathrm{CI}$ is $13 \%$ higher than standard deviation of NI. By the analysis of 86 companies from New Zealand, Kabir, \& Laswad (2011, p. 275 and p. 281) determined that the standard deviation of CI is higher than standard deviation of NI, but that this difference, however, is not statistically significant.

Regarding the researches that have for its subject the practice of financial statements on $\mathrm{CI}$ that refer to the companies from the real sector in RS, three relevant studies can be singled out (Obradović \& Karapavlović, 2015; Obradović \& Karapavlović, 2017; Karapavlović, 2018). All three researches have shown that (1) between NI and NCI there is a high positive correlation, (2) NI and NCI statistically do not differ significantly, (3) NCI is more volatile in time in relation to NI and (4) revaluation surplus, gains or losses on financial instruments available for sale and gains or losses on the defined employee benefit plans are the most common components of OCI. Obradović \& Karapavlović $(2015$, p. 61; 2017, p. 120) established that companies have, on average, one component of OCI, while Karapavlović (2018, p. 272) established that the companies have, on average, 0.44 components of OCI. The percentage of companies in which there are no 
components of $\mathrm{OCI}$, i.e. whose $\mathrm{NCI}$ is equal to $\mathrm{NI}$, in the mentioned studies that refer to RS is in range $20.59-65 \%$.

\section{RESEARCH SAMPLE AND METHODOLOGY}

At the end of 2018, that was the final year included in this research, there were 20 companies in RS, out of which 16 were insurance companies and the remaining 4 were reinsurance companies (National Bank of Serbia, 2019, p. 13). In this research, all insurance companies have been included. All analyzed IC have the legal form of stock company, which was expected regarding that IC its shareholders capital earn from emission and share sale (Stančić, 2018, p. 767). The analysis was primarily implemented at the level of entire population, and after that the segmentation of the observed IC was carried out to (1) non-life IC, (2) life IC and (3) mixed companies (both life and non-life insurance). In Table 1, IC that were included in the research have been shown.

Table 1. Insurance companies in $R S$ included in the research

\begin{tabular}{ll}
\hline AMS Insurance & Uniqa non-life Insurance \\
DDOR Novi Sad & Uniqa life insurance \\
Generali Insurance Serbia & Merkur Insurance \\
Globos Insurance & Dunav Insurance \\
Grawe Insurance & OTP Insurance \\
Milenijum Insurance & Sava non-life Insurance \\
Sogaz & Sava life Insurance \\
Triglav Insurance & Wiener Städtische Insurance \\
\hline
\end{tabular}

The period the analysis refers to is from 2014 to 2018 , and individual annual financial statements of IC have been used. The choice of 2014 for the initial period of the analysis was conditioned by the fact that the sets of financial statements for 2014 were the first annual financial statements in which reporting entities in RS, as well as IC, present the components of OCI, net OCI and NCI. The collected data were processed by using the software package IBM SPSS 20 Statistics and Microsoft Excel program. For data processing, primarily, the analysis of financial statements contents has been used, by which the components of OCI that have been represented in these statements have been determined. For the testing of the first hypothesis descriptive statistics was also used, so that the average number of the components of OCI in IC in RS would be determined. By the comparison of the obtained results with the results of the research in the real sector in RS (Obradović \& Karapavlović, 2015; Obradović \& Karapavlović, 2017; Karapavlović, 2018), the conclusion on the acceptability of the first hypothesis will be made. The second hypothesis was tested with the help of the correlation 
coefficient and Wilcoxon Signed-rank test. The correlation between NI and NCI was examined via Pearson correlation coefficient, and Wilcoxon Signed-rank test was used for the examination of the possible statistically significant difference between NI and NCI. This test was used since the forms of periodic income of IC were observed from the two aspects. The first is the analysis of NI, and the second implies the addition of the components of OCI, so that NCI would be obtained. Dispersion measures (variance and standard deviation) were used for the testing of the third hypothesis. We have used significance level $(\alpha)$ of 0.01 and 0.05 to determine statistical significance.

The examination of data usability for the analysis in this paper was based on the examination of (1) the quality of financial reporting standards that IC use when preparing and presenting financial statements and (2) the degree to which IC really comply with these standards (adjusted according to: Obradović \& Karapavlović, 2017a, p. 333). Unlike some companies from the real sector that, in the period which the analysis in this paper refers to, have the possibility of choice of financial statement basis according to that period valid, as well as current Law on accounting (The Official Gazette of RS, No 62/2013, 30/2018; The Official Gazette of RS, No 73/2019), IC in RS belong to the category of reporting entities that are the obligors of the application of the full version of IFRS. Having in mind that IFRS worldwide have been considered as the quality basis of financial reporting, it is evident that the analyzed IC have good predispositions for preparing financial statements of good quality and usable for the analysis (Obradović \& Karapavlović, 2017a, p. 333). The data peculiarities that are being showed in financial statements of IC dictates that these statements are the subject of mandatory audit (Stančić, 2016, p. 42), so that the examination of the opinion of the external audit is the way of making specific and direct impression on the quality of input data. Out of the total 80 sets of financial statements each of 16 IC in a five-year period, $66(82.50 \%)$ sets obtained non-modified positive opinion. Financial statements of $10(62.5 \%)$ IC had unqualified (positive) opinion continuously from 2014 to 2018. The unqualified opinion with the emphasis of matter obtained 13 (16.25\%) sets. Financial statements of one IC had that type of opinion during the observed period, while financial statements of three IC had that type of opinion for two consecutive years. Financial statements of one IC had unqualified opinion with the emphasis of matter in only one year, and only one set obtained qualified opinion (the basis was the correction of statements from the previous year, which was not included in the analysis, so that in 2014 the qualified opinion due to the question of data comparability was given). Thus, the quality of input data in this research on the basis of the opinion of external audit can be considered satisfying. 


\section{RESEARCH RESULTS}

\section{Number and Existence of OCI Components in Serbian IC (H1)}

The pattern of Statement of other comprehensive income for IC in $\mathrm{RS}$ is partially different in relation to the pattern of the same report that is prescribed for the companies from real sector. All the components of OCI displayed in that report in the companies from the real sector also exist in the pattern of Statement of other comprehensive income for IC. Each of these components according to both mentioned patterns are shown in the way that gains are shown separately, and losses separately, which is an example of respecting the gross principle. Relying on previous researches that were related to the RS whose results were shown previously, when analyzing the number of OCI components, we treated the gains and losses on the same basis as one component.

Based on Table 2, in which the components of OCI that appear at least once in IC in RS are presented, it can be concluded that gains or losses on financial instruments available for sale are the most represented component of OCI. At the second place, according to the representation are gains or losses on the defined employee benefit plans, and then changes in the revaluation surplus of property, plant, equipment and intangible assets. The remaining components of OCI are practically not represented in the Serbian IC, with the exception of gains or losses on investment in equity instruments that appears in one IC only in 2014. Also, other not realized gains and other not realized losses appear only in one IC in the first four years covered by the analysis. That component of OCI is not shown in the Statement of other comprehensive income of the companies from the real sector.

Table 2. Components of OCI in Serbian IC

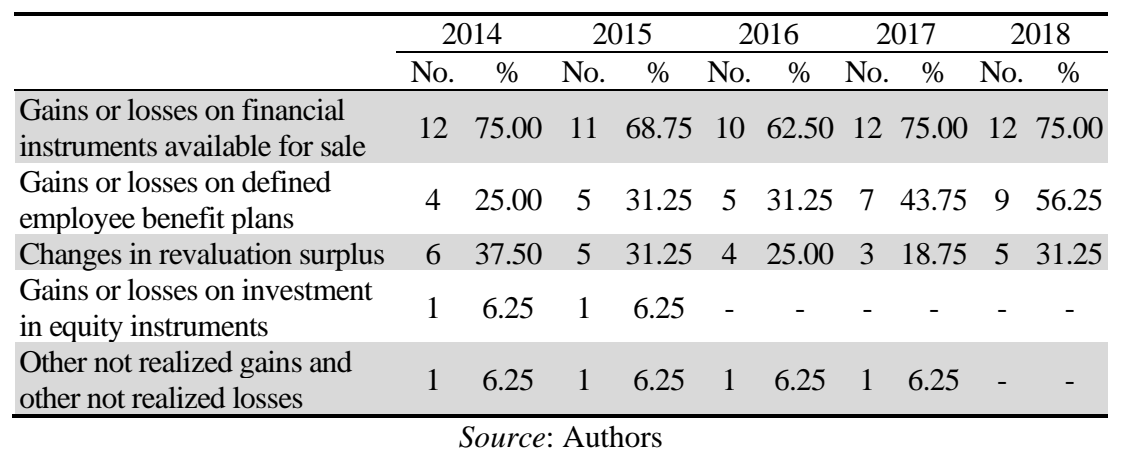

The second difference between the pattern of the Statement of other comprehensive income for IC and the companies from the real sector is related to the way of filling in the position of gross other 
comprehensive income, i.e. gross other comprehensive loss. Namely, we noticed that with the companies from the real sector, depending on the presence of positive or negative components of OCI in larger amount they are filled either by one or by other position, which means that the gross principle has not been fully complied with. However, it does not mean that users of their financial statements are deprived of information of the amount of gross other comprehensive income or loss whose amounts can be reached by returning a step back and by the inspection of individual components of OCI. With IC, both positions are filled, and their difference is then possibly reduced by the amount of the tax on OCI, in order to obtain NCI. On average, Statements of other comprehensive income of 3 $(18.75 \%)$ IC contain the position tax on OCI, while the remaining IC, in which the components of OCI occur, do not have that position, which means that their gross OCI and net OCI are equal. The publication of IFRS 17 - Insurance Contracts in May 2017, which will be effective on January 1, 2021 and which will replace IFRS 4 of the same name, influenced one of the modifications of IAS 1 in terms of the components of OCI. The list of OCI components according to IAS 1 has been updated, among other things, starting from the specificities of insurance business and, thus, financial reporting of IC (see IASB, 2018, paragraph 7). In this regard, some future research should show the influence of this modification on the practices of financial reporting on OCI of IC.

On average, the considered IC have per $1.5 \mathrm{OCI}$ components each, whereby none of the IC has more than three components during the observed period. At least one OCI component has $14(87.5 \%)$ IC, while of the remaining $2(12.5 \%)$ one has only in one year. On average, in $9(56.25 \%)$ IC OCI is positive, which means that NCI is larger than NI, while in $5(31.25 \%)$ IC OCI is negative, which means that NCI is lower than NI.

Most of the components of OCI, on average, have the mixed IC that perform the activity of life and non-life insurance (1.8). Among them, on average the most components of OCI are present with the Dunav Insurance Company (2.4), which is also the highest value in entire population. This company, observed through the years individually, is among the ones that have the biggest number of components, 3 per year in 2015 and 2016. The mentioned company is also the largest participant in the insurance sector in $\mathrm{RS}$ at the end of the observed period, by occupying $26.8 \%$ of the market, according to the criteria of the total premium (National Bank of Serbia, 2019, 16). Two more companies from this segment of IC have the number of components of OCI above average, precisely per 2.0 (Generali Insurance and Triglav Insurance, which according to the mentioned criteria of total premium are on the $2^{\text {nd }}$ and the $5^{\text {th }}$ place, respectively). The smallest number of the components of OCI in this market segment has Grawe Insurance, with 1 component continuously (gains or losses on financial instruments available for sale). 
In the second place according to the average number of the components of OCI is the sector of non-life insurance (1.4). The company that only in the last year of the observed period has one component of OCI (Uniqa non-life insurance) belongs to this segment of the market. By excluding this company, the sector of non-life insurance would have the average of 1.7 components of OCI. However, 3 companies are even above that (higher) average, more precisely AMS Insurance with 2.2 components, Milenijum Insurance with 2.0 components and Sava non-life insurance-with 1.8 components.

In the third place, according to the average number of the components of OCI, there are life IC, that on average have one OCI component. The company that did not have any components of OCI (OTP Insurance) in the observed period belongs to this segment of the market. Excluding this company, the life insurance sector would have the average of 1.3 components of OCI, but in this case of 2 companies would be above the average, namely, Merkur Insurance with 1.6 components and Sava Life Insurance with 1.4 components.

\section{The Influence of OCI on NCI in Serbian IC (H2)}

The values of coefficients of the correlation between NI and NCI in the period from 2014 to 2018 are $0.945,0.969,0.985,0.967$ and 0.992 , respectively, whereby the correlation is significant at the level $\alpha=0.01$. These values show that between NI and NCI of IC there is a high positive correlation that is equalized during the observed period. The correlation with all three types of IC is high and positive, whereby the highest is in the case of life IC, and the lowest is in case of IC that perform both insurance activities.

Given that NI and NCI of IC in all the five observed periods do not have normal distribution, for testing the hypothesis on their statistical significance we used non-parameter technique - Wilcoxon Signed-rank test. The results of that test displayed in Table 3 show that in the period from 2014 to 2018 NI and NCI of IC are not statistically significantly different, which was to be expected given the values of the previously established coefficients of the correlation between those two forms of the periodic result. Indicator of the size of influence $r$, obtained by dividing the value of $\mathrm{Z}$ by the square root of $\mathrm{N}$, whereby $N$ is the number of observations in two time moments, and not the number of population elements (Pallant, 2011, p. 233), shows that in 2014 between NI and NCI there is very little difference $(r=0.1)$, while in the remaining four years the difference is of medium intensity $(r=0.3)$. Obtained results show that the OCI components of IC do not make NCI significantly different from NI. However, this does not mean that the difference between NI and NCI is not significant in all IC. In this regard, two extreme cases can be singled out: (1) net loss of 19,941,000 RSD has transformed into net 
comprehensive profit of 389,000 RSD and (2) net profit of 596,000 RSD has transformed into net comprehensive loss of 742,507,000 RSD.

Table 3. Wilcoxon Signed Ranks Tests (NI and NCI)

\begin{tabular}{cccccc}
\hline \multicolumn{7}{c}{ Population } \\
\hline$Z$ & 2014 & 2015 & 2017 & 2018 \\
\hline$P$ & -0.345 & -1.726 & -1.915 & -1.538 & -1.533 \\
$r$ & 0.730 & 0.084 & 0.056 & 0.124 & 0.125 \\
\hline \multicolumn{7}{c}{ Non-life insurance companies } & 0.3 & 0.3 \\
\hline$Z$ & 0.1 & -0.944 & -0.405 & -0.135 & -0.524 \\
$p$ & -0.135 & 0.345 & 0.686 & 0.893 & 0.600 \\
$r$ & 0.893 & 0.2 & 0.1 & 0.02 & 0.1 \\
\hline$Z$ & 0.02 & Life insurance companies & \\
\hline$p$ & -0.535 & -1.604 & -1.604 & -1.604 & 0.000 \\
$r$ & 0.593 & 0.109 & 0.109 & 0.109 & 1.000 \\
\hline \multicolumn{7}{c}{0.3} & 0.3 & 0.3 & 0.000 \\
\hline$Z$ & 0.1 & 0.3 & -109 \\
$p$ & -0.524 & -1.992 & -1.572 & -1.363 \\
$r$ & 0.600 & 0.046 & 0.116 & 0.173 & 0.046 \\
\hline \multicolumn{7}{c}{0.4} & 0.3 & 0.2 & 0.4 \\
\hline
\end{tabular}

Table 3 also suggests that NI and NCI of non-life IC and life IC are not statistically significantly different. However, in case of IC that perform both the activities, there is a statistically significant difference between these two forms of results in 2015 and $2018(p=\alpha=0.05)$ that is, according to Cohen's criterion, (Pallant, 2011, p. 233) of medium intensity $(r=0.4)$ and it is close to the difference of high intensity. Additional analysis has shown that medians of NI and NCI in all five years differ most in the case of IC that perform both insurance activities, and that medians differ the least in case of life IC. Apart from that, as it was previously established, IC that perform both the activities, on average have the most components of OCI that influence the difference between medians of NI and NCI in all five observed years and the statistically significant difference between these two forms of results in 2015 and 2018. Finally, only in the case of IC that perform both insurance activities, there is no IC which NI and NCI are equal in any of the five observed years.

\section{The Volatility of NI and NCI in Serbian IC (H3)}

In order to examine the volatility of NI and NCI, their changes in the form of difference of the appropriate amounts in consecutive years of the observed period have been established. 
Table 4. Standard deviations and variances of changes in NI and NCI

\begin{tabular}{|c|c|c|c|}
\hline & Change in & St. dev. & Variance \\
\hline \multicolumn{4}{|c|}{ Population } \\
\hline \multirow{2}{*}{ 2015-2014 } & NI & $553,792.77$ & $326,736,516,728.96$ \\
\hline & NCI & $874,731.92$ & $765,155,931,501.73$ \\
\hline \multirow{2}{*}{ 2016-2015 } & NI & $208,610.38$ & $42,360,306,582.52$ \\
\hline & NCI & $287,079.40$ & $82,414,581,965.48$ \\
\hline \multirow{2}{*}{$2017-2016$} & NI & $113,105.14$ & $13,501,415,539.63$ \\
\hline & NCI & $410,731.20$ & $168,700,118,774.38$ \\
\hline \multirow{2}{*}{ 2018-2017 } & NI & $259,016.94$ & $69,442,338,593.31$ \\
\hline & NCI & $572,192.54$ & $327,404,302,954.12$ \\
\hline \multicolumn{4}{|c|}{ Non-life insurance companies } \\
\hline \multirow{2}{*}{$2015-2014$} & $\mathrm{NI}$ & $336,434.19$ & $113,187,966,309.37$ \\
\hline & NCI & $157,621.13$ & $24,844,419,682.70$ \\
\hline \multirow{2}{*}{ 2016-2015 } & NI & $256,618.14$ & $65,852,867,827.87$ \\
\hline & NCI & $253,336.11$ & $64,179,184,275.50$ \\
\hline \multirow{2}{*}{$2017-2016$} & NI & $81,075.01$ & $6,573,156,470.97$ \\
\hline & NCI & $77,763.60$ & $6,047,177,905.07$ \\
\hline \multirow{2}{*}{$2018-2017$} & NI & $142,833.88$ & $20,401,518,188.40$ \\
\hline & NCI & $146,802.16$ & $21,550,873,146.80$ \\
\hline \multicolumn{4}{|c|}{ Life insurance companies } \\
\hline \multirow{2}{*}{$2015-2014$} & $\mathrm{NI}$ & $30,591.42$ & $935,835,189.30$ \\
\hline & $\mathrm{NCI}$ & $29,431.69$ & $866,224,201.30$ \\
\hline \multirow{2}{*}{ 2016-2015 } & $\mathrm{NI}$ & $38,696.55$ & $1,497,423,053.80$ \\
\hline & NCI & $43,372.12$ & $1,881,141,088.70$ \\
\hline \multirow{2}{*}{ 2017-2016 } & NI & $91,815.83$ & $8,430,146,891.00$ \\
\hline & NCI & $86,016.71$ & $7,398,874,671.30$ \\
\hline \multirow{2}{*}{ 2018-2017 } & NI & $85,613.14$ & $7,329,610,380.70$ \\
\hline & NCI & $83,772.89$ & $7,017,897,391.30$ \\
\hline \multicolumn{4}{|c|}{ Insurance companies performing both insurance activities } \\
\hline \multirow{2}{*}{$2015-2014$} & NI & $717,327.40$ & $514,558,600,674.24$ \\
\hline & NCI & $1,129,190.15$ & $1,275,070,392,441.29$ \\
\hline \multirow{2}{*}{$2016-2015$} & NI & $198,992.55$ & $39,598,034,559.62$ \\
\hline & NCI & $328,400.13$ & $107,846,645,589.48$ \\
\hline \multirow{2}{*}{ 2017-2016 } & NI & $156,995.35$ & $24,647,539,031.33$ \\
\hline & $\mathrm{NCI}$ & $660,586.49$ & $436,374,514,302.67$ \\
\hline \multirow{2}{*}{$2018-2017$} & $\mathrm{NI}$ & $343,095.37$ & $117,714,432,394.14$ \\
\hline & NCI & $833,555.77$ & $694,815,227,259.29$ \\
\hline
\end{tabular}

According to Table 4, standard deviation and variance of change in $\mathrm{NCI}$ are higher than standard deviation and variance of change in NI. It means that NCI of IC is more volatile than NI. For that reason, as well as due to the fact that in individual cases there is a difference between these two forms of results, which is sometimes significant (as well as with companies from the real sector) the users of financial statements of IC should also take into account NI and NCI when assessing their performances 
and forecasting business operations and performances in the future (Karapavlović, 2018, p. 278).

$\mathrm{NCI}$ is more volatile than NI in the whole observed period only in the case of IC that perform both insurance activities. In case of non-life IC, NCI is more volatile than NI only in 2018 compared to the 2017, while NI is more volatile than NCI in 2015 compared to the 2014, in 2016 compared to the 2015 and in 2017 compared to the 2016. In case of life IC, NCI is more volatile than NI only in 2016 compared to the 2015, while in 2015 compared to the 2014, in 2017 compared to the 2016 and in 2018 compared to the $2017 \mathrm{NI}$ is more volatile.

\section{CONCLUSION}

Although the literature dedicated to $\mathrm{CI}$ is diverse, the research that had for its subject the practice of financial statements on CI of IC from RS is not known to the authors of this paper, which is the key contribution of this paper. The scope of only IC from one country is the main deficiency of this paper. In that sense, IC from the developing countries should be included in future research (such as RS), and then from developed countries and the obtained results compared.

By comparing the results in this paper with the results of the research from RS available to the authors that had for its subject the consideration of the practice of financial reporting on CI of the companies from the real sector (Obradović \& Karapavlović, 2015; Obradović \& Karapavlović, 2017; Karapavlović, 2018) it can be concluded that, on average, in IC, more components of OCI were represented than in the companies from the real sector. Gains or losses on financial instruments available for sale are the most represented component of OCI, which can be explained by the fact that IC, apart from performing the activity of insurance, represent important investors on financial and other markets, i.e. that the investment activity is their second most important activity. The following two components are actuarial gains or losses on the defined employee benefit plans and the changes in revaluation surplus of property, plant, equipment and intangible assets. These three components of OCI are mostly represented in the Statement of other comprehensive income of companies from the real sector, but in less percentage of companies (on average $11.8 \%, 12.40 \%$ and $17.4 \%$, respectively) than it is the case with IC (on average, $71.25 \%, 37.50 \%$ and $28.75 \%$, respectively). Furthermore, the percentage of IC at which OCI does not exist is significantly lower than the percentage of companies from the real sector. On the basis of the above mentioned, the first hypothesis can be accepted.

Wilcoxon Signed-rank tests have shown that statistically NI and NCI do not differ significantly. However, there are some cases in which there are significant differences between these two forms of income. 
Specifically, in case of IC that perform both insurance activities (life and non-life insurance), it was determined that in 2015 and 2018 there is a statistically significant difference between these two forms of income. In that sense, the second hypothesis cannot be completely rejected. The research also showed that between NI and NCI there is a high and positive correlation, whereby the correlation is the largest in case of life IC, and the smallest in case of IC that perform both insurance activities.

Since standard deviation and variance change in NCI in each year of the observed period are higher than the standard deviation and variance change in NI, it can be concluded that NCI of IC is more volatile in time than NI, which is in accordance with the theoretical assumptions, the results of quoted research from RS and other countries. However, the third hypothesis cannot be accepted in total, since that segmentation of the insurance market gives a different image. Namely, NCI is more volatile than NI during the entire observed period only in the case of IC that perform both insurance activities, while in the case of life IC and non-life IC NI is more volatile.

\section{REFERENCES}

Brauchle, G.J., \& Reither, C.L. (1997). SFAS No. 130: Reporting Comprehensive income. The CPA Journal, 67(10). Retrieved from http://ezproxy.nb.rs:2271/ehost/detail/ detail?vid=5\&sid=ba5ce0f1-c048-4003-8f16-8bf9afc8aaf2\%40sessionmgr101\& bdata=JnNpdGU9ZWhvc3QtbGl2ZQ\%3d\%3d\#AN=9710304616\&db=buh (May 5, 2020)

De Cristofaro, T., \& Falzago, B. (2014). What trend for Comprehensive Income Presentation? Evidence from Italy. International Journal of Accounting and Taxation, 2(3), 17-40. doi: 10.15640/ijat.v2n3a2

Dhaliwal, D., Subramanyam, K.R., \& Trezevant, R. (1999). Is comprehensive income superior to net income as a measure of firm performance? Journal of Accounting and Economics, 26(1-3), 43-67. doi: 10.1016/S0165-4101(98)00033-0

Goncharov, I., \& Hodgson, A. (2011). Measuring and Reporting Income in Europe. Journal of International Accounting Research, 10(1), 27-59. doi: 10.2308/ jiar.2011.10.1.27

Henry, E. (2011). Presentation of Comprehensive Income: Another (Small) Step Toward Convergence. The Journal of Corporate Accounting \& Finance, 23(1), 85-90. doi: 10.1002/jcaf.21726

International Accounting Standards Board. (2018). International Accounting Standard (IAS) 1: Presentation of Financial Statements. London, UK: IFRS Foundation.

Jovković, B.Č. (2018). Karakteristike finansijskih izveštaja osiguravajućih kompanija i njihova revizija [Characteristics of Insurance Companies' Financial Statements and Their Audit]. Poslovna ekonomija, 12(1), 110-126. doi: 10.5937/poseko13-16143

Kabir, M.H., \& Laswad, K.F. (2011). Properties of net income and total comprehensive income: New Zealand evidence. Accounting Research Journal, 24(3), 268-289. doi: 10.1108/10309611111187000

Karapavlović, N. (2018). Merni atributi u finansijskom izveštavanju i periodični rezultat preduzeća (PhD thesis). [Measurement Attributes in Financial Reporting and Periodical Income of Company] Retrieved from http://nardus.mpn.gov.rs/ 
bitstream/handle/123456789/11172/Disertacija.pdf?sequence=6\&isAllowed=y (May 11, 2020)

Ketz, E. (1999). Comprehensive Income: What Do the Numbers Disclose? The Journal of Corporate Accounting \& Finance, 10(4), 79-96. doi: 10.1002/(SICI)10970053(199922)10:4<79::AID-JCAF8>3.0.CO;2-L

Khan, S., \& Bradbury, M.E. (2014). Volatility and risk relevance of comprehensive income. Journal of Contemporary Accounting \& Economics, 10(1), 76-85.doi: 10.1016/j.jcae.2014.01.001

Khan, S., \& Bradbury, M.E. (2016). The volatility of comprehensive income and its association with market risk. Accounting \& Finance, 56(3), 727-748. doi: 10.1111/ acfi. 12108

Khan, S., Bradbury, M.E., \& Courtenay, S. (2018). Value Relevance of Comprehensive Income. Australian Accounting Review, 28(2), 279-287. doi: 10.1111/auar.12181

Kreuze, J.G., \& Newell, G.E. (1999). The Relationship of Net Income to Comprehensive Income: An Analysis of Fortune 500 Companies. American Journal of Business, 14(1), 53-58. doi: 10.1108/19355181199900005

Kubota, K., Suda, K., \& Takehara, H. (2011). Information Content of Other Comprehensive Income and Net Income: Evidence for Japanese Firms. AsiaPacific Journal of Accounting \& Economics, 18(2), 145-168. doi: 10.1080/ 16081625.2011 .9720879

Lapková, M., \& Stašová, J. (2014). Recogniton of comprehensive income in Slovak companies. Accounting Theory and Practice, 15, 8-14. doi: 10.15388/batp.2014. 15.1

Mahmood, J., \& Mahmood, I. (2019). Comprehensive income disclosure (the case of US companies). Cogent Economics \& Finance, 7(1), 1674587. doi: 10.1080/ 23322039.2019.1674587

Maines, L.A., \& McDaniel, L.S. (2000). Effects of Comprehensive-Income Characteristics on Nonprofessional Investors' Judgments: The Role of Financial-Statement Presentation Format. The Accounting Review, 75(2), 179-207. doi: 10.2308/accr. 2000.75.2.179

Narodna banka Srbije. (2019). Sektor osiguranja u Republici Srbiji: Izveštaj za 2018. godinu. [Insurance sector in the Republic of Serbia: Report for 2018] Retrieved from https://www.nbs.rs/internet/latinica/60/60_6/izvestaji/izv_IV_2018.pdf (May 4, 2020)

Ngmenipuo, I. M. (2015). The Impact of Comprehensive Income Reporting on Financial Performance of Ghanian Firms with Public Accountability. International Journal of Economics, Commerce and Management, 3(3). Retrieved from http://ijecm.co. uk/wp-content/uploads/2015/03/3330.pdf (September 11, 2015)

Obradović, V. (2014). Inconsistent application of international financial reporting standards. Economic Horizons, 16(3), 231-243. doi: 10.5937/ekonhor1403239O

Obradović, V., \& Karapavlović, N. (2015). Finansijsko izveštavanje o ukupnom dobitku ili gubitku - slučaj nefinansijskih kompanija iz indeksne korpe BELEX-line [Financial Reporting on Comprehensive Profit or Loss - the Case of Nonfinancial companies from Belex-line Index Basket]. Računovodstvo, 59(4), 49-64.

Obradović, V., \& Karapavlović, N. (2017). Financial reporting of comprehensive income in the food and beverage sector in the Republic of Serbia. Economics of Agriculture, 64(1), 113-128. doi: 10.5937/ekoPolj17011130

Obradović, V., \& Karapavlović, N. (2017a). Analiza finansijskog položaja i rentabilnosti privrednih subjekata iz Šumadije i Pomoravlja [Analysis of financial position and performance of business entities from Šumadija and Pomoravlje district]. U Veselinović, P., Makojević, N., Slavković, M. (Ed.), Uticaj globalizacije na poslovno upravljanje i ekonomski razvoj Sumadije i Pomoravlja [The influence of globalization on business management and economic development of Šumadija 
and Pomoravlje district] (str. 331-346). Kragujevac: Univerzitet u Kragujevcu, Ekonomski fakultet.

Pallant, J. (2011). SPSS - Priručnik za preživljavanje [SPSS - Survival Manual]. Beograd: Mikro knjiga.

Păşcan, I. (2014). Does comprehensive income tell us more about an entity's performance compared to net income? Study on Romanian listed entities. Procedia Economics and Finance, 15, 1077-1082. doi: 10.1016/S2212-5671(14)00559-0

Popović, Z., Stanković, J. J., \& Marjanović, I. (2020). Ocena uspešnosti poslovanja osiguravajućih kompanija: integrisani AHP-VIKOR metod [Performance Evaluation of Insurance Companies: An Integrated AHP-VIKOR Method]. Ekonomske ideje i praksa, 36, 7-20.

Rees, L.L., \& Shane, P.B. (2012). Academic Research and Standard-Setting: The Case of Other Comprehensive Income. Accounting Horizons, 26(4), 789-815. doi: 10. 2308/acch-50237

The Official Gazette of RS, No. 135/2014, 102/2015. Odluka o Kontnom okviru i sadržini računa u Kontnom okviru za društva za osiguranje [Decision on the Chart of Accounts and Content of Accounts in the Chart of Accounts for Insurance Undertakings].

Smith, P.A., \& Tse, S. (1998). Reporting Comprehensive Income: Does It Realy Affect Stock Prices? The Journal of Corporate Accounting \& Finance, 9(4), 75-86. doi: 10.1002/jcaf.3970090408

Stančić, P., Dimitrijević, D., \& Stančić, V. (2013). Forenzičko računovodstvo - odgovor profesije na prevare u finansijskim izveštajima [Forensic Accounting - the Response of the Profession to Financial Statement Frauds]. Teme, 37(4), 1879-1897.

Stančić, V. (2016). Finansijsko-računovodstveni aspekti kreiranja investicionog portfolija kompanija za životno osiguranje. (PhD thesis). [Financial and Accounting Aspects of Investment Portfolio Creating in Life Insurance Companies] Retrieved from http://nardus.mpn.gov.rs/bitstream/handle/123456789/8242/Disertacija.pdf?sequen ce $=6 \&$ isAllowed $=y$ (May 11, 2020)

Stančić, V. (2018). Finansijsko-računovodstveni aspekti tehničkih rezervi kompanija za životno osiguranje u Srbiji [Financial and Accounting Aspects of Technical Provisions in Life Insurance Companies in Serbia], U Ivanović, V., Zlatanović, D., Nikolić, J., Kalinić, Z., Jovković, B., Janković, N. (Ed.), Implikacije ekonomije znanja za razvoje procese u Republici Srbiji [Implications of knowledge economy for development process in the Republic of Serbia] (str. 765-775). Kragujevac: Ekonomski fakultet Univerziteta u Kragujevcu.

Stojilković, M., \& Spasić, D. (2002). Izveštaj o promenama na kapitalu (II deo) normativna regulisanost i praksa izveštavanja prema US-GAAP i UK-GAAP i pravci harmonizacije [The Statement of Changes in Equity - normative regulation and reporting practices according to US-GAAP an UK-GAAP and directions of harmonization]. Računovodstvo, 46(12), 14-22. 


\title{
ФИНАНСИЈСКО ИЗВЕШТАВАЊЕ О УКУПНОМ РЕЗУЛТАТУ - СЛУЧАЈ ОСИГУРАВАЈУЋИХ ДРУШТАВА ИЗ РЕПУБЛИКЕ СРБИЈЕ
}

\author{
Немања Карапавловић ${ }^{1}$, Владимир Станчић ${ }^{1}$, Евица Петровић $^{2}$ \\ ${ }^{1}$ Универзитет у Крагујевцу, Економски факултет, Крагујевац, Република Србија \\ ${ }^{2}$ Универзитет у Нишу, Економски факултет, Ниш, Република Србија
}

\section{Резиме}

Циљ рада је да се истражи да ли специфичности делатности осигурања утичу на то да се у осигуравајућим друштвима појављује више компоненти осталог укупног резултата, као и да ли су у осигуравајућим друштвима заступљене другачије компоненте осталог укупног резултата у поређењу са предузећима из реалног сектора. Осим тога, рад треба да покаже да ли се нето резултат и нето укупан резултат осигуравајућих друштава значајно разликују и који од њих је променљивији у времену. Резултати истраживања сугеришу да је у осигуравајућим друштвима заступљено више компоненти осталог укупног резултата него у предузећима из реалног сектора, као и да се најзаступљеније компоненте осталог укупног резултата код осигуравајућих друштава не разликују од предузећа из реалног сектора, али да је њихова учесталост појављивања већа. Статистичка анализа спроведена на нивоу популације показала је да се нето резултат и нето укупан резултат не разликују значајно. Такође, утврђено је да је нето укупан резултат осигуравајућих друштава променљивији у времену у односу на нето резултат. Међутим, сегментацијом укупне популације према врстама осигурања којима се баве осигуравајућа друштва на она која обављају искључиво делатност неживотног осигурања, она која обављају искључиво делатност животног осигурања и она која обављају делатности и неживотног и животног осигурања, утврђено је да се у извесним случајевима нето резултат и нето укупан резултат статистички значајно разликују. Конкретно, у случају осигуравајућих друштава која обављају делатности и неживотног и животног осигурања, утврђено је да у 2015. и 2018. години постоји статистички значајна разлика између ова два облика резултата. Осим тога, поменута сегментација укупне популације показала је да је нето укупан резултат променљивији од нето резултата током целог посматраног периода само у случају осигуравајућих друштава која обављају делатности и неживотног и животног осигурања, док је код оних која обављају искључиво делатност неживотног осигурања и оних која обављају искључиво делатност животног осигурања у већој мери променљивији нето резултат. Обухват самоосигуравајућих друштава из једне државе главни је недостатак који се овом истраживању може приписати. У том смислу, будућим истраживањима треба обухватити осигуравајућа друштва из земаља у развоју, као што је Република Србија, а потом из развијених земаља и упоредити добијене резултате. 